\title{
Chemical Analysis and Microbial Population of Belacan Depik, Fermented Fish Product of Rasbora tawarensis
}

\author{
Eva Murlida, C. Nilda, and Murna Muzaifa* \\ Post-Harvest Technology Department, Universitas Syiah Kuala, Jalan, Banda Aceh, Indonesia \\ ${ }^{*}$ Corresponding author. Email: murnamuzaifa@ unsyiah.ac.id
}

\begin{abstract}
Depik (Rasbora tawarensis) is a typical endemic fish of Lake Laut Tawar in Central Aceh Regency, Indonesia. Local people process depik fish into fresh, dried and fermented forms. Femented depik fish called belacan depik, which is one of favorite food by local community. However, research on the quality of depik belacan and the microorganisms involved in its fermentation is still very limited. This research is an exploratory laboratory research that aims to analyze the quality of fermented depik fish and its microoganism population. The parameters analyzed consisted of nutritional analysis in the form of proximate analysis (moisture, ash, protein, fat and fiber content) and microbiological analysis through total plate count (TPC) analysis of total mesophilic bacteria, lactic acid bacteria and fungi. The results showed that fermented depik fish had moisture content of $45.56 \pm 0.23 \%$, protein $22.06 \pm 0.95 \%$, fat 4.33 $\pm 0.27 \%$, ash $10.83 \pm 0.43 \%$ and fiber $1.58 \pm 0.11 \%$. The population of microorganisms was dominated by mesophilic bacteria, followed by fungi and lactic acid bacteria. The presence of a population of depik belacan microorganisms is expected to be the basis for further research to characterize and identify microorganisms involvedin depik fish fermentation.
\end{abstract}

Keywords: Aceh, Belacan, Depik, Fermentation.

\section{INTRODUCTION}

Fish is well-known as source of animal protein. Depik fish (Rasbora tawarensis) is one of the freshwater fish, which contributed as main protein source for the Gayo people who inhabit the central part of Aceh province, Indonesia. According to Weber's classification, depik fish belong to the Crypinidae tribe and the Rasbora clan which are known as indigenous freshwater fish [1,2]. Currently, the existence of depik fish is become of main concern, its population is declining sharply and has been designated as a fish with a threatened status (threatened species) by the IUCN [3]. Environmental degradation, the introduction of foreign fish, destructive fishing techniques, pollution and global climate change are some of the factors that cause the depik fish population declined [4,5].

The declining population of depik fish affectedthe decreasing of production and the price is getting more expensive. However, consumer interest in depik fish remains high. Consumers usually buy depik fish in fresh or processed form such as of dried depik fish and belacan depik as shown in Figure 1 [1].



Figure 1. Depik fish and its processed product [1]. 
Belacan depik is a fermented depik processed with the addition of salt and special spices such as laos, turmeric and lemongrass [6,7]. The field survey showed that the quality of the depik belacan found in the market is very diverse. This diversity can be influenced by many factors, including raw materials, processing methods and differences in additional ingredients or spices used during processing [8].

Fermentation is one of the processing methods applied in the manufacture of belacan depik. During fermentation, a number of enzyme and microbial activities can occur in breaking down organic components that cause modification of texture, aroma and taste [9], resulting in the unique characteristics of belacan products. The study nutritional aspect of the belacan depik is still very limited, as well as its microbiological aspect. So far, the microorganisms in depik fish fermentation are not clearly known. Whereas as a fermented product, the involvement of microorganisms plays an important role in determining the quality of belacan depik. Biochemical changes during fermentation can affect the quality of the final product. Therefore, as a basic research, it is necessary to do chemical analysis of belacan depik and its microorganism population.

\section{METHODS}

\subsection{Raw material preparation}

The raw materials for processing belacan depik are depik fish and spices consisting of mint leaves (Mentha piperita), galangal (Alpinia galanga), turmeric (Curcuma longa), torch ginger flowers (Etlingera elatior) and lemongrass (Cymbopogon citratus). These materials are obtained from fishermen who live around Lake Laut Tawar and traditional markets in Takengon, Central Aceh. Freshly caught depik fish are washed, cleaned and dried in the sun for 2 days until dry. This dried depik fish will be used for making depik belacan.

\subsection{Processing of belacan depik}

The manufacture of depik belacan refers to the manufacture of depik belacan carried out by Rahmi et al., [1] with slight modifications. $2 \mathrm{~kg}$ of dried depik fish added with $100 \mathrm{~g}$ of salt, $1 \mathrm{~kg}$ of galanga, and other spices with each about $2 \%$ of the raw materials used. This mixture is then ground into a tightly closed container and fermented for 7 days. This fermented product is called belacan depik, with paste form and greenish-brown color [6].

\subsection{Product analysis}

The analysis carried out on the belacan depik are chemical and microbiological analysis. Chemical analysis carried out includes proximate analysis (moisture, ash, protein, fat and fiber content) [10]. Microbiological analysis is carried out using the total plate count (TPC) method to analyze of the population of microorganisms, especially mesophilic bacteria, lactic acid bacteria and fungi. The media used for microorganism population analysis consisted of nutrient agar (NA) for mesophilic bacteria analysis, de Man Rogosa Sharpe agar (MRSA) for lactic acid bacteria and Sabouraud dextrose agar (SDA) for fungi. Each treatment analysis was repeated 3 times. The data obtained are the average values, displayed in the form of figures and tables and analyzed descriptively.

\section{RESULT AND DISCUSSION}

\subsection{Chemical analysis}

The belacan depik produced in paste form (slightly dense), green-brown color and slightly fibrous. The results of the complete analysis of moisture content, protein, fat, ash and fiber can be seen in Table 1.

Table 1. Chemical analysis of belacan depik

\begin{tabular}{|l|l|l|}
\hline No & Chemical Analysis & Mean \pm Std (\%) \\
\hline 1 & Moisture & $45.56 \pm 0.23$ \\
\hline 2 & Protein & $22.06 \pm 0.95$ \\
\hline 3 & Fat & $4.33 \pm 0.27$ \\
\hline 4 & Ash & $10.83 \pm 0.43$ \\
\hline 5 & Fiber & $1.58 \pm 0.11$ \\
\hline
\end{tabular}

Table 1 described that moisture content of belacan depik is $45.56 \pm 0.23 \%$. This result is higher than moisture content of dry depik as the raw material, which is $5.71 \%$ [1]. The increasing moisture content of belacan depik compared to the raw material is due to the fermentation process that produces water in the reaction and the addition of spices that content water than the dried depik fish. Belacan depik can be categorized into pasta products, not too wet and not too dry, due to its water content. The moisture content of the belacan depik in this study is slightly lower than the commercial belacan depik in traditional markets [6], but higher than Rahmi et al [1] result which is $39.22 \%$. Compared to fermented products in general, belacan depik has a lower moisture content. Fish fermented products in Asia have moisture content ranging from $56.1-70.9 \%$ [11]. 
The protein content of belacan depik is 22.06 $\pm 0.95 \%$, which is an important nutrient in belacan Nurhayati et al., [12] stated that fish with a protein content of $15-20 \%$ is classified in the high protein fish group. The protein content of belacan depik in this study was lower than fermented fish and shrimp which generally reached $30.38 \%$ [13]. The fat content of belacan depik was $4.33 \pm 0.27 \%$, also slightly lower than that of fermented shrimp paste, which was $4.89 \%$. This difference value can be caused by differences in the types of fish used [13].

Ash content is a mineral element as an inorganic substance or ash in food [14]. The ash content of belacan depik is $10.83 \pm 0.43 \%$. The ash content in this belacan depik is quite high, resulted from the added salt. Belacan depik is processed by adding up to $10 \%$ salt and the addition of a number of fresh ingredients such as galangal, turmeric, lemongrass leaves and curry leaves. The addition of these ingredients contributes to the increase in the ash content of fermented depik fish [8]. The ash content in this study was lower than Muzaifa [6] and Yuliadi [8] at 8.22\% and 6.99\%, respectively.

Fiber content in depik belacan is $1.58 \pm 0.11 \%$. The fiber in belacan depik is due to the addition of fresh spice ingredients at the beginning of the process of belacan depik. This fiber content mainly comes from the main spices, such as galangal and other spices (turmeric, lemongrass and other additional leaves). Galangal is used more than other spices as mentioned by Muzaifa [6] and Yuliadi [8]. Galangal is known contain about more than $20 \%$ fiber and the amount is higher in older galangal [15].

\subsection{Microbial analysis of belacan depik}

Belacan depik is one of the products produced through a fermentation process and of course involves a number of microorganisms in its processing. Microbiological analysis was carried out by counting the total mesophilic bacteria, lactic acid bacteria and fungi. The results of the microbiological analysis of the depik belacan can be seen in Table 2 .

Table 2. Microbial population of belacan depik.

\begin{tabular}{|l|l|}
\hline \multicolumn{1}{|c|}{ Microorganism } & Total Plate Count (CFU/g) \\
\hline Mesofilic Bacteria & $2 \times 105$ \\
\hline Fungi & $1 \times 103$ \\
\hline Lactic acid bacteria & $5 \times 102$ \\
\hline
\end{tabular}

Mesophilic bacteria were the highest bacteria found in belacan depik reaching $2 \times 10^{5} \mathrm{CFU} / \mathrm{g}$. Mesophilic bacteria are bacteria that generally exist at moderate temperatures or normal conditions. Belacan depik with fish raw materials is known contain sufficient protein and water so that it is very good for the growth of microorganisms. Pseudomonas sp., Bacillus sp. and Aeromonas sp., are bacteria commonly found in freshwater fish [16]. In addition to mesophilic bacteria, the presence of lactic acid bacteria was also detected. Total lactic acid bacteria obtained in belacan depik was $5 \times 10^{2} \mathrm{CFU} / \mathrm{g}$, lower than mesophilic bacteria and fungi which reached $1 \times 10^{3} \mathrm{CFU} / \mathrm{g}$. The presence of lactic acid bacteria in belacan depik is suspected due to the involvement of the fermentation process. The fermentation process is able to provide suitable conditions for the growth of lactic acid bacteria. The addition of salt and curing of belacan depik (fermentation in a tightly closed container) are the main factors that encourage the growth of lactic acid bacteria. This result is in accordance with Molin [17] and Holzapfel [18] who state that the growth of lactic acid bacteria occurs immediately on organic material that is closed in such a way that it limits oxygen. The presence of fungi in fermented fish is also common. Zang et al.,

[19] have also identified 153 fungi (mushrooms) associated with the typical Chinese fermented fish product, Suan $\mathrm{Yu}$. The main groups of fungi identified were Aspergillus, Candida, Cladosporium, Saccharomyces, Wickerhamomyces, Fusicolla, Torulaspora, Fusarium and Aureobasidim. Through this research, it can be seen that mesophilic bacteria, lactic acid bacteria and fungi are found in belacan depik. However, so far there has been no research reporting any type of bacteria involved in depik fish fermentation. This is an opportunity for further research to characterize and identify microorganisms that are involved and beneficial in producing quality belacan depik products.

\section{CONCLUSION}

The belacan depik produced in paste form (slightly dense), green-brown color and slightly fibrous. Belacan depik had moisture content of $45.56 \pm 0.23 \%$, protein 22.06 $\pm 0.95 \%$, fat $4.33 \pm 0.27 \%$, ash $10.83 \pm 0.43 \%$ andfiber $1.58 \pm 0.11 \%$. The population of microorganisms was dominated by mesophilic bacteria, followed by fungi and lactic acid bacteria. The presence of a population of depik belacan microorganisms is expected to be the basis for further research to 
characterize and identify microorganisms involved in depik fishfermentation.

\section{ACKNOWLEDGMENTS}

Thanks to Syiah Kuala University for supporting this research through the 2021 Research Grant "Penelitian Lektor". Thank you to Faidha Rahmi who have helped in belacan depik preparation.

\section{REFERENCES}

[1] Rahmi F, Susanti Z, Nilda C., and Muzaifa M. 2021. IOP Conf. Series: Earth and Environmental Science. 644: 012049

[2] Bleeker. 1998. Rasboras, Keeping and Breeding them in Captivity. New Jersey: TFHPublicaton.

[3] CBSG. 2003. Conservation Assessment and Management Plan for Sumatran Threatened Species: Final Report. IUCN SSC Conservation Breeding Specialist Group, Apple Valley, MN, USA.

[4] Muchlisin Z.A. 2008. Buletin Leuser 6 9-12

[5] Ayuniara. 2019. Analisis Faktor-Faktor yang Mempengaruhi Populasi Ikan Depik (Rasbora tawarensis) di Danau Laut Tawar Kabupaten Aceh Tengah Sebagai Referensi Mata Kuliah Ekologi dan Masalah Lingkungan. Skripsi. Universitas Islam Negeri ArRaniry. Banda Aceh

[6] Muzaifa M. 2015. SAGU. J.Agric Sci.Technol. 14 19-22

[7] Muzaifa M, Eva M, Martunis. 2015. IbM Usaha belacan depik (Rasbora tawarensis), ikan fermentasi khas dari gayo. Report. Universitas Syiah Kuala

[8] Yuliadi N. 2015. Kajian Proses Pembuatan dan Mutu Produk Belacan Depik (Rasbora tawarensis) di Kabupaten Aceh Tengah. Skripsi. Universitas Syiah Kuala. Banda Aceh.

[9] Alexandraki V.E., Tsakalidou.K., Papadimitrioui $\mathrm{W}$ and Holzapfel. 2013. Food and Agriculture Organization of the United Nations Report. $65 \mathrm{p}$ 172.

[10] AOAC. 2005. Official Methode of Analysis. Association of Analytical Chemist, Washington D.C.

[11] Yoshiko Y. 1989. Food Rev International. 14: 213-46

[12] Nurhayati T, Salamah E and Hidayat, T. 2007. Bul. Teknol. Has. Perikan. 10 23-34.
[13] Cho H. S. and Kim KH. 2009. J. East Asian Soc Diatery Life. 19: 395-400

[14] Winarno. 2008. Kimia Pangan dan Gizi. Jakarta: Gramedia Pustaka Utama.

[15] Bermawie N, Purwiyanti S, Melati and Meilawati N L 2012 Bul. Penelit. Tanam.Rempah dan Obat. 23: $125-135$

[16] Nursyirwani. 2003 Ilmu Kelautan. 8: 8-15.

[17] Molin G. 2003. In Handbook of Fermented Functional Food. Boca Raton: CRC Press

[18] Holzapfel W.H. and Wood B.J.B. 1995. In The Genera of Lactid Acid Bacteria. London: Blackie Academic \& Professional

[20] Zang J, Xu Y, Xia W, Yu D, Gao P, Jiang Q and Yang F 2018 Food Res. Int. 111 565-73 [7] E. Clarke, O. Grumberg, S. Jha, et al., Counterexample-guided abstraction refinement, in: E.A. Emerson, A.P. Sistla (Eds.), Computer Aided Verification, Springer, Berlin, Heidelberg, 2000, pp. 154-169. DOI: https://doi.org/10.1007/10722167_15 